\title{
Study on the Efficiency of the Different units for Removing Metallic ions in Isfahan Water Treatment Plant
}

\author{
*AFSHIN MALEKI ${ }^{1}$, BABAK ROSHANI ${ }^{1}$, FARHAM KARAKANI ${ }^{2}$ \\ ${ }^{1}$ Dept. of Environmental Health Engineering, Kurdistan University of Medical Sciences, Sanandaj, Iran \\ ${ }^{2}$ Dept. of Environmental Health Engineering, Tehran University of Medical Sciences, Tehran, Iran
}

\begin{abstract}
In this study, removal efficiency of heavy metals such as iron, manganese, copper and nickel were surveyed in various units of water treatment plant in Isfahan City. Samples were taken from influent, before and after sedimentation and after filtration under standard condition. Concentration of heavy metals in each sample was measured by atomic absorption spectrophotometer. The results showed that removal efficiency of iron, manganese, copper and nickel were 71, 60, 79 and 40 percent, respectively. Experimental results currently showed low efficiency for the suitable removal of aluminum. So, the aluminum concentration in all the samples from the influent ( $\left.2.03 \mathrm{mg} \mathrm{l}^{-1}\right)$ and effluent $\left(2 \mathrm{mg} \mathrm{l}^{-1}\right)$ of the water treatment plant exceeded the EPA drinking water standard $\left(50 \mu \mathrm{g} \mathrm{l}^{-1}\right)$. It is concluded that using conventional treatment technology can reduce metal concentrations conform to internationally approved guidelines except for aluminum. @ JASEM
\end{abstract}

Surface water receives various contaminants such as heavy metals salts during their movement. Metallic salts are partially soluble in water, and in high concentration could be harmful. The sources of metals in natural waters are dissolution of natural sediments, and discharging domestic, industrial and agricultural wastewaters (Walter, 1981). Metallic ions in water enter to water treatment plants; hence treatment processes should have the ability to remove these matters. Metal ions release in consequence of salts dissolution. Some of these ions are iron, manganese, copper and nickel. Removal efficiency of these ions is affected by type of process and conditions that are prevailing in treatment process.

Iron concentration in most of surface water resources is high, due to presence of the iron salts in watersheds and constituent of river-bed. Increase of iron in water results in forming of suspended and colloidal particles in combination with organics or minerals. Although presence of iron has no health effects, but in high concentrations affects on water quality, causes sediment agglomeration in distribution networks, accelerates iron bacteria growth, and consequently increases corrosion in network (Walter, 1981). Maximum permissible concentration of iron is $0.3 \mathrm{mg}$ $\mathrm{l}^{-1}$ (Amman, 1995). A low amount of this element is harmful. In presence oxygen or after chlorination is precipitable as oxide and forms black sludge slims, and release of this slims affects on taste, odor and quality of water. Manganese accelerates bacterial growths (e.g. manengobacteria) which have taste and odor problems. Standard in drinking water is $0.05 \mathrm{mg}$ $\mathrm{l}^{-1}$ (Amman, 1995). Copper salts are discharged through industrial wastewaters. Also they are used to control of biological growth in reservoirs and water transport lines. Although copper is an essential micronutrient, but in high concentration causes taste and odor in water and also has physiological effects in human. Presence of copper along with zinc, iron and lead is network corrosion suggestive (Zuan, 1997). Maximum permissible concentration is $1 \mathrm{mg} \mathrm{l}^{-}$ ${ }^{1}$ (Amman, 1995). Nickel salts are entered to surface waters through industrial wastewater especially electro-plating industries. Nickel compounds have lower toxicity in comparison with other compounds. Presence of nickel inclined to carbonyl ions has remarkable toxicity. There are some reports on serious damages due to accidental drinking of polluted waters by nickel (WHO, 1991). There are no acceptable standards for nickel (Amman, 1995). Aluminum (Al) is the most abundant metal in the earth's crust (Storey and Masters, 1995; Glynn et al., 1999). Typically, a portion of the alum added to the raw water is not removed during treatment and remains as residual aluminum in treated water (Driscoll and Letterman, 1988; Van Benschoten and Edzwald, 1990). There is considerable concern throughout the world over the levels of aluminum found in drinking water sources (raw water) and treated drinking water (Srinivasan et al., 1999). A high (3.6 to $6 \mu \mathrm{g} \mathrm{l}^{-1}$ ) concentration of aluminum may precipitate as aluminum hydroxide giving rise to consumer complaints (Srinivasan et al., 1999; Lopez et al., 2002). Aluminum is also a suspected causative agent of neurological disorders such as Alzheimer's disease and presenile dementia (Srinivasan et al., 1999; Lopez et al., 2002; Gardner and Gunn, 1991; Jekel, 1991). Treatment process should decrease the concentration of the metals below of standards.

The purpose of this study is to determine metals removal efficiency (iron, manganese, copper, nickel and aluminum) in various units in Isfahan Water Treatment Plans.

\section{MATERIALS AND METHODS}

Samples were taken from various parts of water treatment process, include: intake, rapid mix, before and after filters, and effluent. Samples were taken 
using Grab method, with plastic container according to Standard Methods for the Examination of Water and Wastewater (APHA, AWWA, WPCF, 1995). Samples were analyzed less than $2 \mathrm{~h}$ after sampling. Samples were taken for one month, and preservation was accomplished by adding nitric acid down to $\mathrm{pH}$ 2. Samples were analyzed using Perkin Elmer Atomic Absorption, Model 2380. The Aluminum concentrations were determined by Spectrophotometery Eriochrom Cianin R method (APHA, AWWA, WPCF, 1995).

\section{RESULTS AND DISCUSSION}

Water treatment process in Isfahan Water Treatment Plant is by conventional method. This means that treatment process during; coagulation, flocculation, sedimentation, filtration and chlorination remove particular and colloidal matters (weather organic or mineral). Because metallic ions were entered to treatment plant in soluble form, treatment process can not remove completely them. Conventional water treatment processes can only reduce relatively metallic salts using trapped salts in flocs during flocculation and then during sedimentation and filtration process (Montgomery, 1985). Also chlorination can oxidizes some metallic salts; and hence can reduce relatively some of oxidized metal solutions. The variations of iron, manganese, copper, nickel and Aluminum in the treatment plant after the water treatment processes are presented in Figs. 1 to 5.

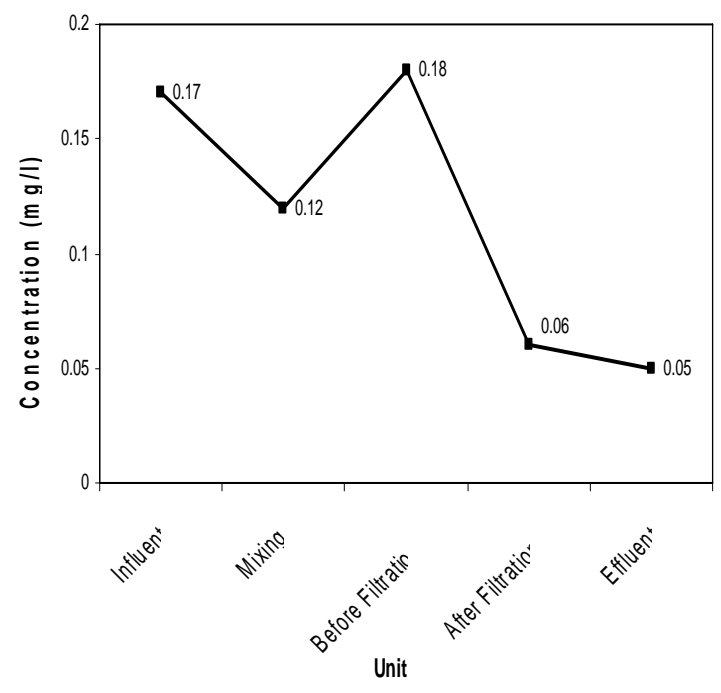

Fig. 1- Iron variation during water treatment process

Afshin Maleki; Babak Roshani; Farham Karakani

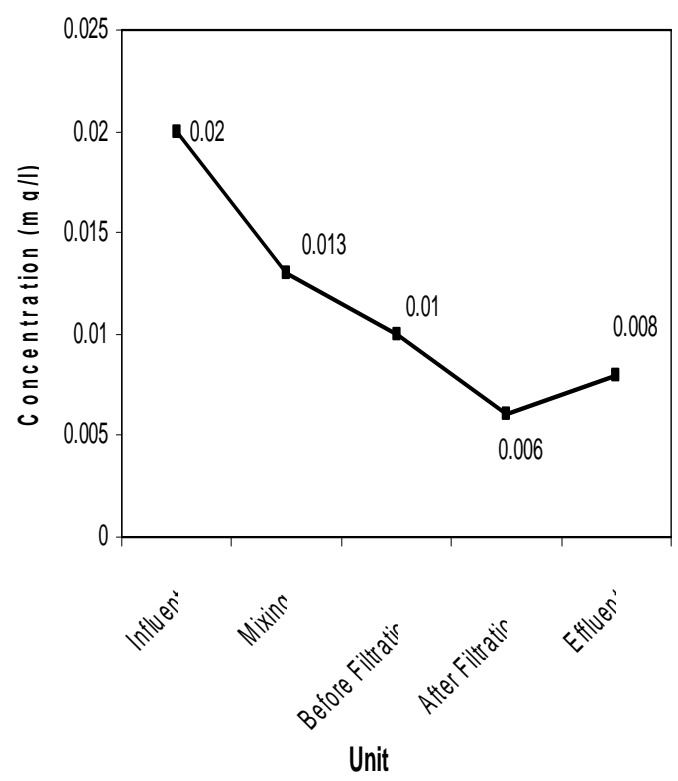

Fig. 2- Manganese variation during water treatment process

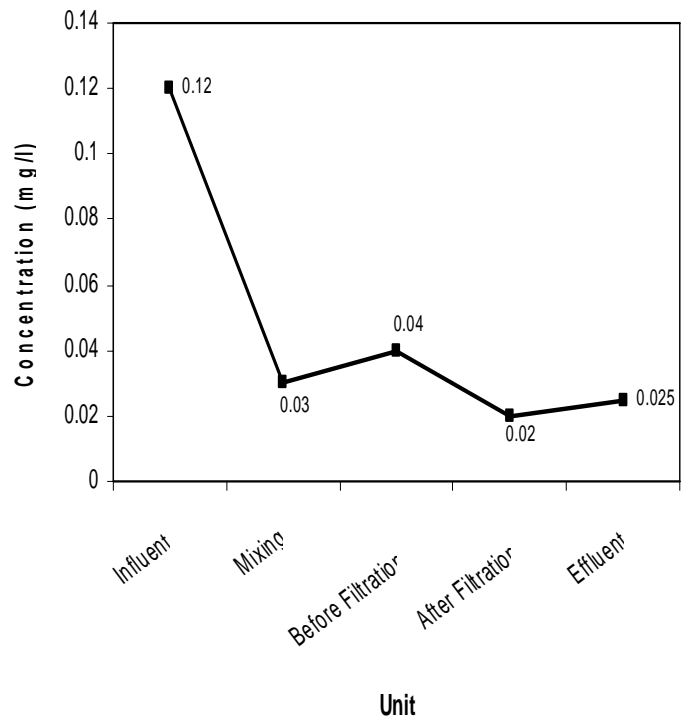

Fig. 3- Copper variation during water treatment process 


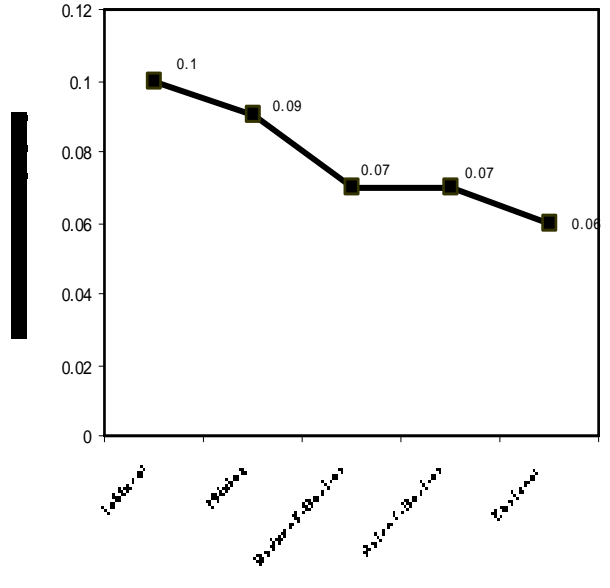

Unit

Fig. 4- Nickel variation during wat er treatment process

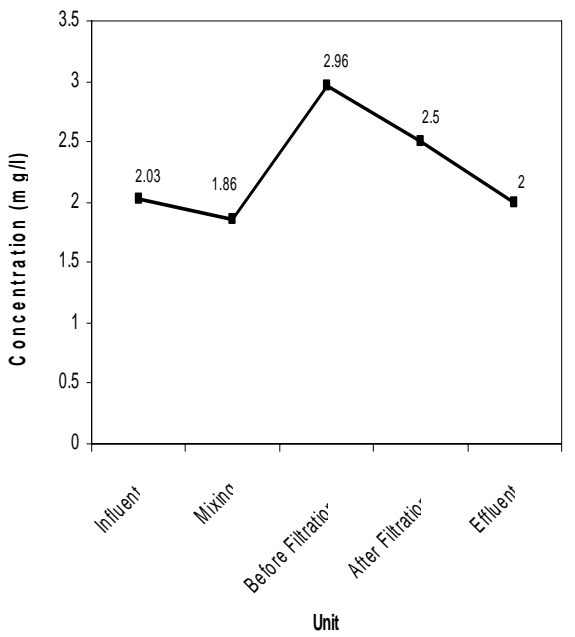

Fig. 5-Aluminum variation during water treatment process

Results showed that concentrations of these pollutants in effluent are lower than influent. Removal efficiency for iron, manganese, copper and nickel is 71, 60, 79 and 40 percent respectively. Variation in manganese and nickel concentration was descending. The most copper removal was in coagulation processes (73 percent), while after that removal was only 5 percent. Floc forming because of application of coagulants containing iron, and iron oxidizing due to aeration before mixing and pre-chlorination reduced iron content in filtered water.

The mean aluminum concentration in the samples collected from influent of the water treatment plant was $2.03 \mathrm{mg} \mathrm{l}^{-1}$, whereas in the samples in effluent of plant was $2 \mathrm{mg} \mathrm{l}^{-1}$ (Fig.5). Results showed that the concentrations of aluminum in all the water samples from the water treatment plant exceeded the EPA drinking water standard. The EPA drinking water standard for aluminum is $50 \mathrm{\mu g} \mathrm{l}^{-1}$ (Dezuane, 1997). The presence of aluminum in influent of the water treatment plant is due to the leakage of aluminum from concrete of the canal before reaching the water treatment plant, or is caused by a low $\mathrm{pH}$ value of raw surface water. The levels found naturally in raw surface water ranged from about 10 to $2000 \mathrm{mg} \mathrm{l}^{-1}$ (Srinivasan et al., 1999). Aluminum levels in areas where surface waters have become acidified $(\mathrm{pH} \sim 4$ to 5) were in excess of $40000 \mathrm{mg} \mathrm{l}^{-1}$ (Srinivasan et al., 1999). The most elevated aluminum concentrations were found in the influent of the filtration unit (mean of $2.96 \mathrm{mg} \mathrm{l}^{-1}$ ). During conventional water treatment processes, aluminum undergoes various transformations (also called speciation of aluminum) which are influenced by factors such as $\mathrm{pH}$, turbidity, temperature of water source, and the organic and inorganic ligands present in water (Srinivasan et al., 1999). Hence, it is clear that there was little change in total aluminum concentration during treatment. Surveys of aluminum speciation by Gardner and Gunn have also shown similar results (Gardner and Gunn, 1991). The same survey on different raw surface water sources and treated water showed that the raw water aluminum was predominantly in particulate form (Srinivasan et al., 1999; Bodek et al., 1988). However, for many water supplies (particularly where aluminum is used as coagulant), the total aluminum concentration increases after treatment. There is reported to be a 40 to $50 \%$ enhance of increase in aluminum concentrations in drinking water over the concentrations in the raw water in plants using Al-based coagulants (Miller et al., 1984). Temperature, $\mathrm{pH}$ and turbidity of the water are important factor in determining aluminum solubility and consequently residual aluminum. As an operational tool to minimize aluminum residuals in finished water, local utilities of Isfahan city should consider determining relationship between residual aluminum and turbidity in their water. Similar results were reported by Jakel about correlation between residual aluminum and effluent turbidity (Jekel, 1991).

Conclusion: The removal efficiency of heavy metals including iron, manganese, copper and nickel were surveyed in various units of water treatment plant in Isfahan City was studied. The results showed that removal efficiency of iron, manganese, copper and nickel were 71, 60, 79 and 40 percent, respectively. In this paper it was showed that metal reduction to levels below internationally approved guidelines is possible using conventional treatment technology. 
Experimental results currently showed low efficiency for the suitable removal of aluminum. So, the aluminum concentration in all the samples from the influent $\left(2.03 \mathrm{mg} \mathrm{l}^{-1}\right)$ and effluent $\left(2 \mathrm{mg} \mathrm{l}^{-1}\right)$ of the water treatment plant exceeded the EPA drinking water standard $\left(50 \mu \mathrm{g} \mathrm{l}^{-1}\right)$.

Acknowledgement: The authors would like to thank the personnel at the Isfahan water treatment plants for providing the water samples and for their cooperation and assistance in the handling of experiments.

\section{REFERENCES}

Amman, J (1995). Guidelines for Drinking Water Quality, Vol. 1, WHO.

APHA, AWWA and WPCF (1995). Standard Methods for the Examination of Water and Wastewater, $19^{\text {th }}$ Ed, Washington.

Bodek, I; Lyman, J W; Rosenblatt, D H (1988). Environmental inorganic chemistry: properties, processes and estimation method. Pergamon Press, Elmsford, N Y, 671.

Dezuane, J (1997). Hand book of drinking water quality. 2nd edition, John Wiley \& Sons.

Driscoll, C T; Letterman, R D (1988). Chemistry and fate of $\mathrm{Al}^{+3}$ in treated drinking water. $\mathrm{j}$ Environ Eng Div 114(1): 21-37.

Droste, L R (1997). Theory and Practice of Water and Wastewater Treatment, John Wiley.

Gardner, M J; Gunn, A M (1991). Bioavailability of aluminum from food and drinking water. Proc. royal. Med.

Round Table Series: Alzheimer's diseases and the environment, London, UK.
Glynn, A W; Sparen, A; Danielsson, L G; Sundstrom, B; Jorhem, L (1999). Concentration dependent absorption of aluminum in rats exposed to labile aluminum in drinking water. J Toxicol Environ Health 56:501 -512.

Jekel, M R (1991). Aluminum in water: How it can be removed? Use of aluminum salts in treatment. Proc. of the Int. Water Supply Ass, Copenhagen, Denmark.

Lopez, F F; Carmen, C; Lorenzo, M L; Lopez, M C (2002). Aluminium content of drinking waters, fruit juices and soft drinks: contribution to dietary intake. The Sci Total Environ 292:205213.

Miller, R G; Kopfler, F C; Ketly, K C., Stober, J A; Ulmer, N S (1984). The occurrence of aluminum in drinking water. J AWWA 76 (1): 84-91.

Montgomery, J M (1985). Water Treatment Principles and Design, John Wiley \& Sons Inc.

Srinivasan, P T; Viraraghavan, T; Subramanian, K S (1999). Aluminum in drinking water: An overview. Wat San 25 (1): 345-349.

Storey, E; Masters, C L (1995). Amyloid, aluminum and the etiology of Alzheimer's disease. Med J Aust 163:256 -259.

Van Benschoten, J E; Edzwald, J K (1990). Measuring aluminum during water treatment: methodology and application. J AWWA 82(5): 71-79.

Walter, I (1981). Handbook of Water Purification, McGraw-Hill.

WHO (1991). International Program on Chemical Safety Environmental Health Criteria.

Zuan, J (1997). Handbook of Drinking Water Quality, Van Nostrand Reinhold. 